Jurnal Keperawatan Silampari

Volume 4, Nomor 2, Juni 2021

e-ISSN: 2581-1975

p-ISSN: 2597-7482

DOI: https://doi.org/10.31539/jks.v4i2.1964

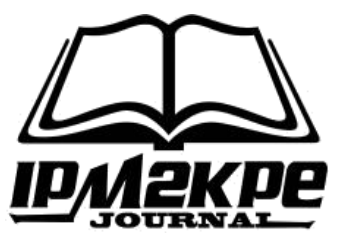

\title{
INTERVENSI PENCEGAHAN BULLYING PADA ANAK BERBASIS SEKOLAH
}

\author{
Ike Sintia Suci ${ }^{1}$, Gusgus Graha Ramdhanie ${ }^{2}$, Henny Suzana Mediani ${ }^{3}$ \\ Universitas Padjadjaran ${ }^{1,2,3}$ \\ ikesintiasuci.97@gmail.com ${ }^{1}$
}

\begin{abstract}
ABSTRAK
Penelitian ini bertujuan untuk meninjau atau melakukan review literature yang berkaitan dengan intervensi pencegahan bulling pada anak berbasis sekolah. Metode Penelitian ini dilakukan dengan metode literature review, artikel diidentifikasi menggunakan elektronik data base, meliputi PubMed, Science Direct, DOAJ, dan ERIC, dengan menggunakan kata kunci yang bertujuan untuk menjawab pertanyaan penelitian yang dirumuskan menggunakan metode PICOS. Hasil penelitian terdapat 5 artikel yang terpilih dari 40 artikel yang sesuai dengan kriteria eligibilitas, berdasarkan hasil analisa ke-5 artikel tersebut memiliki efek yang signifikan terkait intervensi pencegahan bullying berbasis sekolah seperti memasukkan program pencegahan dalam kurikulum atau kegiatan ekstrakurikuler sekolah dengan mengikutsertakan berbagai stakeholder. Simpulan, Intervensi berbasis sekolah terbukti efektif sebagai intervensi pencegahan bullying .
\end{abstract}

Kata Kunci: Bullying, Intervensi, Pencegahan, Sekolah

\begin{abstract}
This study aims to review or review the literature related to school-based bullying prevention interventions in children. Methods This research was conducted using a literature review method. Articles were identified using an electronic database, including PubMed, Science Direct, DOAJ, and ERIC, using keywords to answer research questions formulated using the PICOS method. The results showed that five articles were selected from 40 reports that matched the eligibility criteria. Based on the analysis results, the 5 articles had a significant effect on school-based bullying prevention interventions, such as including prevention programs in the curriculum or school extracurricular activities by involving various stakeholders. In conclusion, school-based intervention proved to be effective as an intervention to prevent bullying .
\end{abstract}

Keywords: Bullying , Intervention, Prevention, School

\section{PENDAHULUAN}

Salah satu isu yang menyita perhatian di dunia pendidikan saat ini adalah kekerasan sekolah yang dilakukan oleh antar siswa, baik aksi tawuran maupun kekerasan yang dilakukan oleh siswa di sekolah berupa tindakan bullying. Kasus bullying di dunia diibaratkan seperti fenomena gunung es yang terlihat kecil di permukaan, namun menyimpan banyak permasalahan yang sebagian besar tidak mudah diketahui atau disadari oleh guru maupun orangtua anak (Riantika, 2020). 
Bullying berasal dari kata bully merupakan suatu kata yang merujuk kepada adanya suatu bentuk "ancaman" yang dilakukan oleh seseorang terhadap orang lain yang umumnya lebih lemah atau "rendah" dari perilaku, yang dapat menimbulkan gangguan psikologis maupun fisik pada korban (korban disebut bully atau bully girl) berupa stress (yang muncul dalam bentuk gangguan fisik atau psikis, atau keduanya; misalnya susah makan, sakit fisik, ketakutan, rendah diri, depresi, cemas dan lainnya (Kurniawan \& Pranowo, 2018). Menurut PEKA (Peduli Karakter Anak) adalah penggunaan agresi dengan tujuan untuk menyakiti orang lain baik secara fisik maupun secara mental. Bullying dapat berupa tekanan fisik, mental verbal maupun emosional dan juga seksual.

Prevalensi kejadian bullying berdasarkan hasil riset dari United Nations Children's Fund (UNICEF) (2017), pada 100.000 anak di 18 negara menunjukkan bahwa 67\% anak mengatakan pernah mengalami bullying dengan berbagai sebab, $25 \%$ dibully karena penampilan fisiknya, 25\% karena jenis kelamin, dan 25\% karena etnis atau negara asal mereka. Menurut hasil Konsultasi Komisi Nasional Perlindungan Anak Indonesia (KPAI) mencatat dalam kurun waktu 9 tahun, dari 2011 sampai 2019, ada 2.473 laporan kejadian bullying didunia pendidikan maupun sosial media dan trennya terus meningkat, kemudian di 18 provinsi Indonesia menunjukkan bahwa sekolah juga merupakan tempat yang berbahaya bagi anak-anak jika ragam kekerasan disitu tidak diantisipasi. Sebanyak 50\% remaja usia 13 sampai 15 tahun di Indonesia pernah mengalami tindakan bullying (UNICEF, 2017). C.S Mott Children's Hospital National mengatakan bahwa bullying termasuk ke dalam 10 masalah kesehatan yang mengkhawatirkan pada remaja (Riantika, 2020).

Korban bullying juga mengalami kekerasan fisik, untuk bullying yang bersifat kekerasan secara fisik. Tindakan kekerasan secara fisik dan verbal yang mereka terima sering menjadi faktor trauma untuk jangka pendek dan jangka panjang. Dampak dari prilaku bullying yang dilakukan dapat mengakibatkan korban menjadi putus asa, malu, menyendiri, tidak mau bergaul, tidak bersemangat, bahkan berhalusinasi. Gangguan tersebut meliputi penyesuaian sosial yang buruk juga gangguan psikologis (Darmayanti et al., 2019). Sejalan dengan penelitian Sufriani \& Sari (2017) menyatakan bahwa kekerasan pada anak akan berpengaruh pada psikologi tumbuh dan kembang anak, dimana anak akan menjadi berkepribadian keras dimasa depan. Anak pelaku bullying berpotensi menjadi pelaku kenakalan remaja, pelaku tindak kekerasan serta pelaku tindak kriminal. Pelaku bullying juga akan kesulitan bersosialisasi dan apabila ini berlangsung hingga dewasa maka akan menimbulkan dampak yang sangat luas, bahkan mengalami permasalahan dalam hubungan sosial, kondisi ekonomi yang memburuk, dan rendahnya well-being ketika menginjak usia 50 tahun (Patras \& Sidiq, 2017).

Upaya pencegahan untuk memutus mata rantai bullying telah dilakukan melalui adalah peran serta dari seluruh pihak, baik pemerintah, guru, tenaga kesehatan, orangtua, peran seorang konselor dari tenaga kesehatan dan peran lingkungan masyarakat serta dari dalam diri anak tersebut sendiri. Sejauh ini, Pemerintah sudah mengeluarkan sebuah kebijakan berdasarkan Peraturan Presiden Nomor 87 Tahun 2017 tentang Penguat Pendidikan Karakter (PPK) yang memiliki tujuan membangun serta membekali siswa sebagai generasi emas Indonesia Tahun 2045 dengan karakter religius, jujur, toleran, disiplin, komunikatif, cinta damai, peduli sosial dan bertanggung jawab sehingga diharapkan siswa tidak melakukan tindakan yang menyimpang.

Penyelenggaraan PKK terintegrasi melalui kegiatan pemberian materi pembelajaran yang menjadi tanggung jawab Kepala Sekolah dan guru (Permen Dikbud No. 20 Tahun 2018). Hal tersebut dijalankan karena menganggap bahwa di Sekolah anak memiliki 
waktu lebih banyak bersama dengan orang lain, sehingga akan mudah belajar memahami karakter berbeda setiap anak. Namun kenyataannya pada penyelenggaraan PKK saat dilakukan evaluasi kebijakan masih belum berjalan secara optimal dikarenakan dalam program tersebut tidak menjelaskan secara detail terkait kesejahteraan anak ataupun terkait kekerasan pada anak terutama bullying (Mustikasari \& Rostyaningsih, 2019). Untuk itu diperlukan tindakan yang nyata dalam menangani perilaku bullying agar dapat mencegah dampak buruk yang di timbulkanya.

Perawat sebagai tenaga kesehatan profesional dapat berkolaborasi dengan sekolah, Perawat dapat menjalankan perannya sebagai pendidik dan advokat untuk anak-anak, orang tua, guru, dan komunitas yang terkait dengan tindakan dan upaya pencegahan, maupun upaya mengatasi trauma atas tindakan bullying (Riantika, 2020). Perawat berperan sebagai konselor dapat bekerja sama dengan stakeholder dalam mengembangkan program-program edukasi terkait bullying, dan sebagai pendidik dapat melakukan pendidikan kesehatan terkait bullying pada anak sebagai upaya pencegahan.

Berdasarkan fenomena tersebut, artikel ini bertujuan untuk meninjau atau melakukan review literature yang berkaitan dengan intervensi pencegahan bulling pada anak berbasis sekolah.

\section{METODE PENELITIAN}

Penelitian ini merupakan penelitian sekunder berjenis literature review, yaitu dengan melakukan peninjauan atau penelaahan secara kritis pengetahuan, gagasan, atau temuan yang didapatkan di dalam tubuh literature dengan berorientasi akademik (academic-oriented literature), serta merumuskan adanya konstribusi teoritis dan metodiologisnya untuk suatu topik tertentu

Strategi Pencarian dimulai dengan menentukan Rearch Question (RQ) yang didasarkan pada 4 elemen yang disebut PICOS (Population, Intervention, Comparison, Outcomes, Study Design). Panduan pertanyaan adalah Kriteria PICOS yang disusun berdasarkan Tabel.1 dibawah ini.

Tabel.1

Kriteria PICOS

\begin{tabular}{ll}
\hline \multicolumn{1}{c}{ Kriteria PICOS } & \multicolumn{1}{c}{ Panduan Pertanyaan } \\
\hline Population/ Problem & $\begin{array}{l}\text { Populasi berasal dari kedua jenis kelamin atau salah satunya } \\
\text { saja dan anak sekolah. }\end{array}$ \\
& $\begin{array}{l}\text { Pendidikan Kesehatan, aktivitas fisik, aplikasi intervensi } \\
\text { Intervention }\end{array}$ \\
& $\begin{array}{l}\text { Mencegahan bullying pada anak berbasis sekolah. } \\
\text { fisik, aplikasi tentang pencegahan kekerasan seksual pada }\end{array}$ \\
& anak \\
Study Design & Quasi-Eksperimen dan Eksperimental. \\
\hline
\end{tabular}

Berdasarkan panduan pertanyaan tersebut, pertanyaan penelitian pada literature ini adalah Intervensi apa yang dilakukan untuk mengurangi bullying di sekolah?.

Pencarian artikel dilakukan melalui database elektronik, meliputi 4 database yaitu PubMed, ScienceDirect, Education Resources Information Center (ERIC) dan DOAJ dengan menggunakan kata kunci yang ada pada Medical Subject Heading (MeSH). Jadi peneliti menggunakan kata kunci yaitu "bullying "AND"school"AND"prevention and control", dengan menerapkan beberapa kriteria inklusi seperti Tahun publikasi artikel berkisar antara 2015-2020, artikel dipublikasi dari database PubMed, ScienceDirect, 
ERIC dan DOAJ, artikel ditulis dalam Bahasa Inggris, Open Akses, berbentuk fulltext format pdf serta penelitian menggunakan desain eksperimen dan RCT. Artikel tentang pengaruh/intervensi pencegahan bullying pada anak berbasis sekolah. Sedangkan kriteria eksklusi adalah Artikel dikeluarkan apabila tidak menggambarkan studi hasil (misalnya; systematic review atau meta analisa, makalah teoritis, penelitian etiologis, bukan artikel akademik atau letter of editor dan laporan kasus, penelitian kualitatif).

Metode yang digunakan dalam pencarian artikel menggunakan metode PRISMA, yang melewati beberapa tahap yaitu identifikasi, penyaringan, kelayakan, dan menentukan artikel terpilih. Tahapan proses pemilihan artikel dapat dilihat pada bagan 1 . Penilain artikel menggunakan format The Joanna Briggs Institute (JBI).
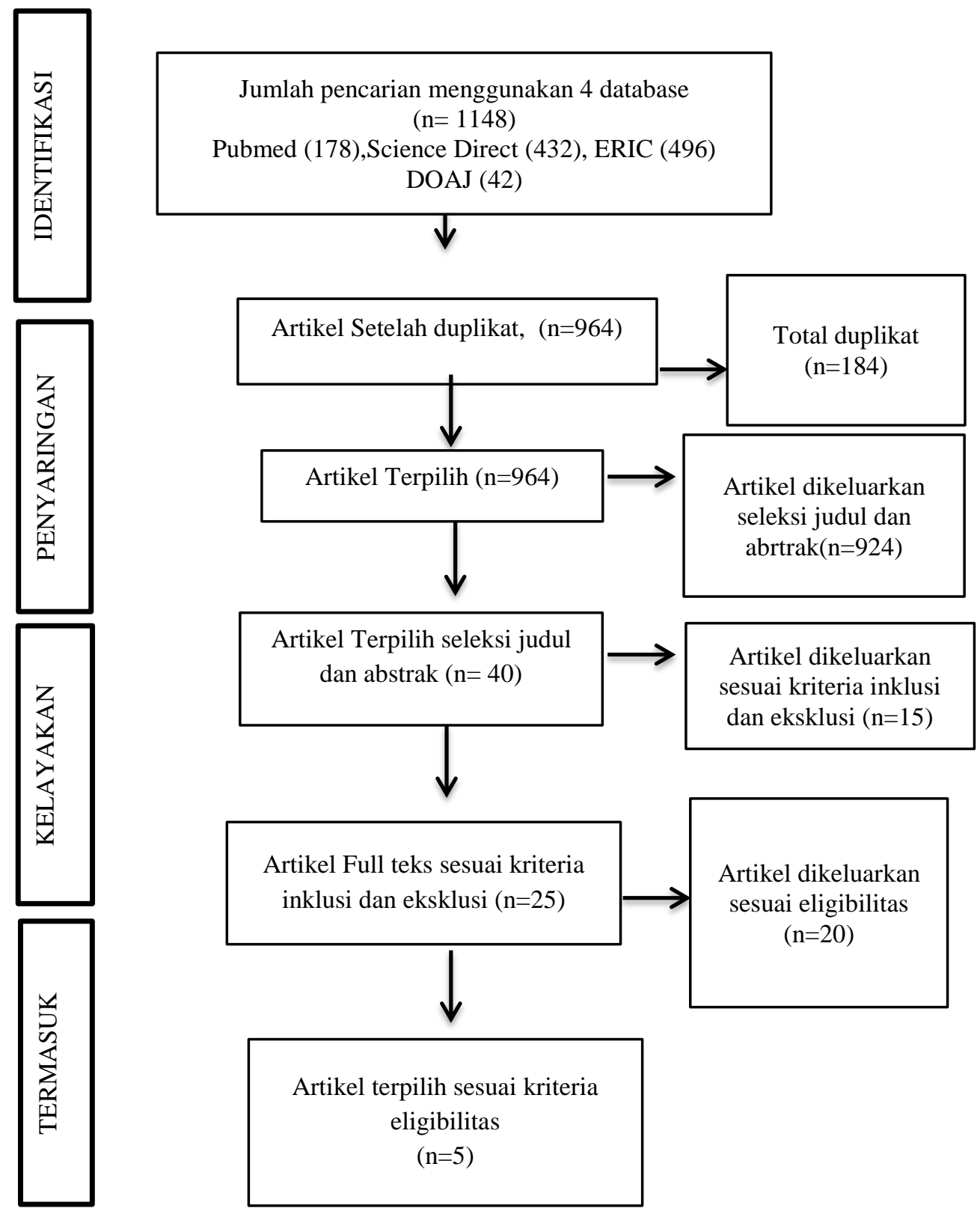

Gambar. 1

Proses Seleksi Literature 
Data diekstraksi dari setiap studi meliputi, metodeologi penelitian (random control trial dan quasi eksperimen), karakteristik pastisipan (anak sekolah), intervensi yang diberikan (metode, durasi dan frekuensi). Berdasarkan seleksi studi, didapatkan jurnal penelitian sebanyak 5 jurnal yang memenuhi kriteria eligibilitas dari total 1148 jurnal yang diidentifikasi.

\section{HASIL PENELITIAN}

Tabel. 2

Literatur Review

\begin{tabular}{|c|c|c|c|c|}
\hline No & $\begin{array}{c}\text { Pengarang, } \\
\text { Judul, Jenis } \\
\text { Literatur }\end{array}$ & Tahun & Tujuan & Hasil Temuan \\
\hline 1. & $\begin{array}{l}\text { Moore et al., } \\
\text { Developing } \\
\text { Wellbeing } \\
\text { Through a } \\
\text { Randomised } \\
\text { Controlled Trial } \\
\text { of a Martial Arts } \\
\text { Based } \\
\text { Intervention: An } \\
\text { Alternative to the } \\
\text { Anti-Bullying } \\
\text { Approach } \\
\text { Randomized } \\
\text { Control Study }\end{array}$ & 2019 & $\begin{array}{l}\text { Untuk mengetahui } \\
\text { kesejahteraan } \\
\text { melalui intervensi } \\
\text { berbasis seni bela } \\
\text { diri: alternatif } \\
\text { pendekatan anti- } \\
\text { bullying }\end{array}$ & $\begin{array}{l}\text { Intervensi psiko-sosial } \\
\text { berbasis seni bela diri } \\
\text { mungkin efektif } \\
\text { metode untuk } \\
\text { meningkatkan hasil } \\
\text { kesejahteraan termasuk } \\
\text { ketahanan dan } \\
\text { pertahanan diri. Studi } \\
\text { menunjukkan bahwa } \\
\text { martial arts ini dapat } \\
\text { menjadi } \\
\text { alternatif dari } \\
\text { pendekatan anti- } \\
\text { bullying dan intervensi } \\
\text { harus ditujukan } \\
\text { membantu individu } \\
\text { mengembangkan } \\
\text { kekuatan dan } \\
\text { mengatasi dengan lebih } \\
\text { efektif, yang memiliki } \\
\text { relevansi khusus } \\
\text { bullying dan } \\
\text { kepentingan yang lebih } \\
\text { umum untuk kesehatan } \\
\text { mental yang positif. }\end{array}$ \\
\hline 2. & $\begin{array}{l}\text { Bonell et al., } \\
\text { Effects of the } \\
\text { Learning } \\
\text { Together } \\
\text { intervention on } \\
\text { bullying and } \\
\text { aggression in } \\
\text { English } \\
\text { secondary } \\
\text { schools } \\
\text { (INCLUSIVE): a } \\
\text { cluster } \\
\text { randomised } \\
\text { controlled trial, } \\
\text { Cluster } \\
\text { Randomised } \\
\text { Controlled Trial }\end{array}$ & 2018 & $\begin{array}{l}\text { Untuk mengetahui } \\
\text { pengaruh } \\
\text { intervensi Belajar } \\
\text { Bersama pada } \\
\text { intimidasi dan } \\
\text { agresi di sekolah } \\
\text { menengah Inggris } \\
\text { (INCLUSIVE) }\end{array}$ & $\begin{array}{l}\text { Learning Together } \\
\text { memiliki efek kecil } \\
\text { tapi signifikan pada } \\
\text { bullying tetapi tidak } \\
\text { berpengaruh pada } \\
\text { perilaku agresi. }\end{array}$ \\
\hline
\end{tabular}




\begin{tabular}{|c|c|c|c|c|}
\hline 3. & $\begin{array}{l}\text { Ferrer-Cascales, } \\
\text { Effectiveness of } \\
\text { the TEI Program } \\
\text { for Bullying and } \\
\text { Cyberbullying } \\
\text { Reduction and } \\
\text { School Climate } \\
\text { Improvement, } \\
\text { Quasy } \\
\text { Eksperimental }\end{array}$ & 2019 & $\begin{array}{l}\text { Untuk mengetahui } \\
\text { Efektivitas } \\
\text { Program TEI untuk } \\
\text { Pengurangan } \\
\text { Bullying dan } \\
\text { Cyberbullying dan } \\
\text { Peningkatan Iklim } \\
\text { Sekolah. }\end{array}$ & $\begin{array}{l}\text { Hasil yang diperoleh } \\
\text { menunjukkan } \\
\text { penurunan perilaku } \\
\text { bullying yang } \\
\text { signifikan, } \\
\text { viktimisasi sebaya, } \\
\text { perkelahian, } \\
\text { penindasan maya, dan } \\
\text { stimulasi dunia maya } \\
\text { dalam kelompok } \\
\text { eksperimental Begitu } \\
\text { pula dengan faktor } \\
\text { perbaikan iklim } \\
\text { sekolah yang signifikan } \\
\text { Hasil yang diperoleh } \\
\text { menunjukkan bahwa } \\
\text { program TEI efektif di } \\
\text { mengurangi perilaku } \\
\text { bully dan cyberbully, } \\
\text { dan pada saat yang } \\
\text { sama, meningkatkan } \\
\text { iklim sekolah. }\end{array}$ \\
\hline 4. & $\begin{array}{l}\text { Salimi, } \\
\text { The Effect of an } \\
\text { Anti-Bullying } \\
\text { Intervention on } \\
\text { Male Students' } \\
\text { Bullying - } \\
\text { victimization } \\
\text { Behaviors and } \\
\text { Social } \\
\text { Competence: A } \\
\text { Randomized } \\
\text { Controlled Trial } \\
\text { in Deprived } \\
\text { Urban Areas. }\end{array}$ & 2019 & $\begin{array}{l}\text { Untuk mengetahui } \\
\text { Pengaruh } \\
\text { Intervensi Anti- } \\
\text { Bullying Terhadap } \\
\text { Perilaku dan } \\
\text { Kompetensi Sosial } \\
\text { Siswa Laki-Laki } \\
\text { Bullying - } \\
\text { victimization }\end{array}$ & $\begin{array}{l}\text { Intervensi yang } \\
\text { didasarkan pada } \\
\text { karakteristik } \\
\text { sosiokultural dan fokus } \\
\text { pada teori SCT } \\
\text { mengurangi } \\
\text { Bullying dan perilaku } \\
\text { viktimisasi. }\end{array}$ \\
\hline 5. & $\begin{array}{l}\text { Axford et al., } \\
\text { The Effectiveness } \\
\text { of the KiVa } \\
\text { Bullying } \\
\text { Prevention } \\
\text { Program in } \\
\text { Wales, UK: } \\
\text { Results from a } \\
\text { Pragmatic } \\
\text { Cluster } \\
\text { Randomized } \\
\text { Controlled Trial, } \\
\text { Pragmatic } \\
\text { Cluster } \\
\text { Randomized } \\
\text { Controlled Tria }\end{array}$ & 2020 & $\begin{array}{l}\text { Untuk mengetahui } \\
\text { Efektivitas } \\
\text { Program } \\
\text { Pencegahan } \\
\text { Penindasan KiVa } \\
\text { di Wales, Inggris }\end{array}$ & $\begin{array}{l}\text { Tidak ada pengaruh } \\
\text { yang signifikan secara } \\
\text { statistik pada hasil } \\
\text { primer dari viktimisasi } \\
\text { yang dilaporkan anak } \\
\text { (intervensi / kontrol } \\
\text { yang disesuaikan OR } \\
0,76 ; 95 \% \text { CI 0,55 } \\
\text { hingga 1,06; p = 0,11) } \\
\text { atau pada hasil } \\
\text { sekunder. Itu } \\
\text { dampak pada } \\
\text { viktimisasi tidak } \\
\text { dibatasi oleh jenis } \\
\text { kelamin anak, usia, } \\
\text { atau status viktimisasi } \\
\text { pada awal. Kepatuhan } \\
\text { pelajaran bagus tapi } \\
\text { eksposur (lama } \\
\text { pelajaran) lebih rendah } \\
\text { dari jumlah yang } \\
\text { direkomendasikan, dan }\end{array}$ \\
\hline
\end{tabular}




\begin{tabular}{ll}
\hline & ada variabilitas yang \\
cukup besar dalam \\
pelaksanaannya \\
seluruh elemen \\
sekolah. Uji coba \\
tersebut menemukan \\
bukti yang tidak cukup \\
untuk menyimpulkan \\
bahwa KiVa \\
berpengaruh pada hasil \\
utama. \\
\hline
\end{tabular}

Berdasarkan hasil analisis ke-5 artikel terkait intervensi berbasis sekolah sebagai upaya pencegahan bullying pada anak, didapatkan bahwa program-program pencegahan tersebut efektif dalam upaya pencegahan bullying. Program-program intervensi yang diberikan adalh berupa pendidikan kesehatan, baik melalui memasukkan pendidikan kesehatan tersebut kedalam kurikulum, kegiatan ekstrakurikuler, maupun pembinaan langsung disekolah. Pendidikan kesehatan merupakan salah satu bentuk strategi intervensi atau upaya mencegah dan mengatasi masalah kesehatan dalam pelayanan keperawatan. Pendidikan kesehatan mencakup pemberian informasi yang sesuai, spesifik, diulang terus menerus, sehingga dapat memfasilitasi perubahan perilaku kesehatan

\section{PEMBAHASAN}

Berdasarkan hasil analisis ke-5 artikel terkait intervensi berbasis sekolah sebagai upaya pencegahan bullying pada anak, didapatkan bahwa program-program pencegahan tersebut efektif dalam upaya pencegahan bullying. Program-program intervensi yang diberikan adalh berupa pendidikan kesehatan, baik melalui memasukkan pendidikan kesehatan tersebut kedalam kurikulum, kegiatan ekstrakurikuler, maupun pembinaan langsung disekolah. Pendidikan kesehatan merupakan salah satu bentuk strategi intervensi atau upaya mencegah dan mengatasi masalah kesehatan dalam pelayanan keperawatan. Pendidikan kesehatan mencakup pemberian informasi yang sesuai, spesifik, diulang terus menerus, sehingga dapat memfasilitasi perubahan perilaku kesehatan (Nocentini et al., 2019).

Terdapat 5 artikel yang ditemukan, dipilih, dan dianalisa, yang sesuai dengan eligibilitas. Dari keseluruhan artikel menunjukkan hasil bahwa terdapat efek yang signifikan dari pemberian intervensi berbasis sekolah dalam pencegahan bullying pada anak (Bonell et al., 2018; Moore et al., 2018; Ferrer-Cascales et al., 2019; Axford et al., 2020; Salimi et al., 2019). Artikel yang didapatkan, 3 berdesain penelitian randomized controll study, dan 2 berdesain quasy eksperimental.

Penelitian pertama yang dilakukan oleh Moore et al., (2018) meneliti tentang penerapan martial arts sebagai salah satu program ekstrakurikuler di sekolah ternyata efektif menjadi alternatif dari pendekatan anti-bullying dan intervensi harus ditujukan membantu individu mengembangkan kekuatan dan mengatasi dengan lebih efektif, yang memiliki relevansi khusus bullying dan kepentingan yang lebih umum untuk kesehatan mental anak yang lebih positif. Penelitian kedua yang dilakukan oleh Bonell et al., (2018) yang menunjukkan bahwa learning together memiliki efek kecil tapi signifikan pada bullying tetapi tidak berpengaruh pada pengurangan perilaku agresi pada anak. Penelitian ketiga yang dilakukan oleh Ferrer-Cascales et al., (2019) menunjukkan bahwa program TEI efektif dalam mengurangi perilaku bully dan cyberbully, dan pada saat yang sama, meningkatkan iklim sekolah yang lebih positif antar siswa/anak. 
Penelitian keempat yang dilakukan oleh Salimi et al., (2019) yang meneliti tentang penerapan kompetensi perilaku dan social dilingkungan sekolah juga memiliki efek yang signifikan dalam mengurangi bullying, viktimisasi antar anak disekolah. Kemudian, penelitian kelima yang diakukan oleh Axford et al., (2020) yang menunjukkan bahwa dengan program tersebut dapat mengurangi kejadian bullying namun belum ada hasil yang akurat bahwa kurikulum tersebut dapat mencegah tidakan bullying secara efektif..

Berdasarkan hasil analisis ke-5 artikel didapatkan bahwa rentang usia sampel dalam pemberian intervensi pencegahan bullying berbasis sekolah adalah anak usia 7-11 tahun. Kemudian, untuk durasi waktu intervensi yang dilakukan oleh peneliti dari ke-5 artikel penelitian rata-rata berkisar lebih dari 4 minggu hingga 3 tahun paling lama dalam menerapkan program intervensi berbasis sekolah (Bonell et al., 2018; Moore et al., 2018; Ferrer-Cascales et al., 2019; Axford et al., 2020; Salimi et al., 2019) menerapkan intervensi berupa program yang memerlukan kerja sama dengan berbagai stakeholder dilingkungan pendidikan seperti dinas pendidikan, kepala sekolah, dan guru dalam pemberian intervensi. 1 artikel memberikan program tambahan ekstrakurikuler disekolah (Moore et al., 2018).

Bullying merupakan perilaku agresif yang dilakukan secara sengaja dan berulang kali, dengan maksud untuk melakukan kekerasan dan pada umunya dilakukan oleh orang yang berkuasa atas korban dalam lingkungan permisif (Nocentini et al., 2019). Bullying terdiri dari beberapa bentuk yaitu; bullying fisik (memukul, menendang, meninju, mendorong dan seterusnya), bullying verbal (mengganti nama panggilan dengan memeberi julukan yang tidak sukai, mengejek, menggoda dan seterusnya), bullying psikis (menyebarkan rumor/gossip, memaksa, mengucilkan dan seterusnya). Merusak barang (merusak barang-barang pribadi atau melakukan sesuatu yang merusak, menghilangkan atau mengambil dengan paksa barang orang lain) dan bullying melalui teknologi (kekerasan melalui pesan teks media sosial) (Kurniasari \& Rahmasari, 2020).

Perilaku bullying dapat mengubah kegiatan di sekolah yang awalnya menyenangkan menjadi menakutkan. Bullying membawa dampak traumatik jangka pendek dan jangka panjang terhadap tahap perkembangan remaja selanjutnya (Shaheen et al, 2018). Pelaku maupun korban akan mengalami masalah gangguan kesehatan mental. Hal tersebut sejalan dengan penelitian (Kurniasari \& Rahmasari, 2020) bahwa korban bullying rentan memiliki ide atau percobaan bunuh diri serta gangguan mental emosional seperti depresi. Dampak dari bullying juga mengakibatkan tingkat ketidakhadiran di sekolah menjadi tinggi dan kehilangan minat untuk mengerjakan tugas sekolah (Salmon et al., 2018).

Dari ke-5 artikel terdapat 2 artikel yang melakukan intervensi berbasis perubahan kurikulum disekolah, sehingga dalam pelaksanaannya memerlukan durasi yang cukup lama yaitu sekitar 3 tahun, karena harus melewati berbagai tahap atau proses, yaitu dimulai dengan mendesiminasikan informasi terkait program, kemudian pelatihan terhadap guru dan murid yang dilakukan oleh tenaga kesehatan ataupun professional terkait kesejahteraan anak, tahap percobaan hingga penerapan kurikulum (Bonell et al., 2018; Ferrer-Cascales et al., 2019). Hal tersebut karena mempetimbangkan bahwa proses pembentukan sikap berlangsung secara bertahap dan melalui proses belajar. Proses belajar mengajar merupakan sesuatu yang paling mendasar dalam perubahan sikap manusia (Bonell et al., 2019). Jika dianalisis sebetulnya program ini sejalan dengan program pemerintah di Indonesia dalam mendukung kebijakan berdasarkan Peraturan Presiden Nomor 87 Tahun 2017 tentang Penguat Pendidikan Karakter (PPK) yang terintegrasi dalam proses pembelajaran disekolah. 
Rentang usia anak dalam pemberian intervensi pencegahan bullying berbasis atau sekolah adalah anak usia 11-17 tahun. Dimana menurut WHO pada usia tersebut anak memasuki tahap pra-remaja dan remaja. Pada tahap awal, remaja mencari-cari nilai dan energi baru serta membandingkan normalitas dengan teman sebaya yang jenis kelaminnya sama, kemudian anak juga pada tahap awal, ketertarikan terhadap teman sebaya ditunjukkan dengan penerimaan atau penolakan. Pada usia tersebut, menurut Jean Piaget anak juga telah memasuki perkembangan kognitif operasional konkret hingga operasional formal, anak sudah mulai memiliki kemampuan untuk berpikir abstrak, mengembangkan informasi yang ia dapatkan dan pelajari dan melakukan refleksi terhadap diri. Sehingga peneitian-penelitian dalam memberikan intervensi pencegahan ataupun mengurangi kejadian bullying tepat diberikan pada anak di usia tersebut agar anak dapat memahami informasi yang disampaikan dengan tepat.

Selanjutnya, berdasarkan analisa dari seluruh artikel dalam pemberian intervensi baik martial arts, learning together, Tutoría Entre Iguales", (program berbasis sekolah intervensi tutor sebaya), dalam pelaksanaannya membutuhkan kerjasama dari berbagai stake holder baik dari lingkungan kesehatan yang ebih memahami terkait bullying dan kekerasan anak, maupun dari lingkungan pendidikan. Dari keseluruhan intervensi selain tenaga kesehatan, guru dan kepala sekolah, ada peran yeng lebih penting yaitu peran teman sebaya (peer) karena dari keseluruhan intervensi yang diberikan menekankan bahwa teman berpengaruh penting dalam pelaksanaan pencegahan bullying pada anak maupun remaja (Wahyudi et al., 2018). Hal tersebut didukung oleh penelitian yang menyatakan bahwa dalam pelaksanaan intervensi bullying di sekolah, teman sebaya memiliki pengaruh yang signifikan terhadap pengetahuan, sikap dan perilaku remaja tentang bullying (Riantika, 2020).

\section{SIMPULAN}

Secara keseluruhan intervensi pencegahan bullying berbasis sekolah secara signifikan dapat meningkatkan pengetahuan anak terhadap bullying dan viktimisasi, sehingga dapat menurunkan angka kejadian bullying pada anak, dengan hasil yang lebih baik jika dalam pelaksanaan program intervensi melibatkan berbagai stakeholder terkait.

\section{SARAN}

Rentang waktu/durasi lamanya intervensi sering menjadi kendala. Durasi pelaksanaan intervensi, biaya, peran orangtuadapat dipertimbangkan dalam penelitian lebih lanjut.

\section{DAFTAR PUSTAKA}

Axford, N., Bjornstad, G., Clarkson, S., Ukoumunne, O. C., Wrigley, Z., Matthews, J., \& Hutchings, J. (2020). The Effectiveness of the Kiva Bullying Prevention Program in Wales, UK: Results from a Pragmatic Cluster Randomized Controlled Trial. Prevention science, 21(5), 615-626. DOI: 10.1007/s11121-020-01103-9

Bonell, C., Allen, E., Warren, E., McGowan, J., Bevilacqua, L., Jamal, F., Legood, R., Wiggins, M., Opondo, C., Mathiot, A., Sturgess, J., Fletcher, A., Sadique, Z., Elbourne, D., Christie, D., Bond, L., Scott, S., \& Viner, R. M. (2018). Effects of the Learning Together Intervention on Bullying and Aggression in English Secondary Schools (Inclusive): A Cluster Randomised Controlled Trial. The Lancet, 392(10163), 2452-2464. https://doi.org/10.1016/S0140-6736(18)31782-3 
Darmayanti, K. H. K., Farida, K., \& Situmorang, D. D. D. (2019). Bullying di sekolah: Pengertian, Dampak, Pembagian dan Cara Menanggulanginya. Pedagogia, 17(1), 55-66. https://ejournal.upi.edu/index.php/pedagogia/article/view/13980

Ferrer-Cascales, R., Albaladejo-Blázquez, N., Sánchez-SanSegundo, M., Portilla-Tamarit, I., Lordan, O., \& Ruiz-Robledillo, N. (2019). Effectiveness of the Tei Program for Bullying and Cyberbullying Reduction and School Climate Improvement. International Journal of Environmental Research and Public Health, 16(4), 580. DOI: 10.3390/ijerph16040580

Kurniasari, A. D. \& Rahmasari, D. (2020). Ide Bunuh Diri pada Korban Bullying . Jurnal $\begin{array}{lll}\text { Penelitian Psikologi, 7(3), 117-122. } & \end{array}$ https://ejournal.unesa.ac.id/index.php/character/article/view/36075

Kurniawan, D. E., \& Pranowo, T. A. (2018). Bimbingan Kelompok dengan Teknik Sosiodrama Sebagai Upaya Mengatasi Perilaku Bullying di Sekolah. Jurnal Bimbingan dan Konseling Terapan, 2(1). DOI: 10.30598/jbkt.v2i1.235

Moore, B., Woodcock, S., \& Dudley, D. (2019). Developing Wellbeing Through a Randomised Controlled Trial of a Martial Arts Based Intervention:An Alternative to the Anti-Bullying Approach. International Journal Environ. Res. Public Health 2, 16(1), 81. DOI: 10.3390/ijerph16010081

Mustikasari, N. A., \& Rostyaningsih, D. (2019). Evaluasi Kebijakan Perlindungan Anak dari Tindak Kekerasan di Kota Semarang . Journal of Public Policy and Management Review, 9(1), 160-174. https://ejournal3.undip.ac.id/index.php/jppmr/article/view/26350

Nocentini, A., Palladino, B. E., Menesini, E. (2019). For Whom is Anti-Bullying Intervention Most Effective? The Role of Temperament. Internasional Journal Res Public Health, 16(3), 388. DOI: 10.3390/ijerph16030388

Patras, Y. E., \& Sidiq, F. (2017). Dampak Bullying bagi Kalangan Siswa Sekolah Dasar. Jurnal Pedagogika dan Dinamika Pendidikan, 5(1), 12-24. 10.30598/pedagogikavol5issue1page12-24

Riantika, E. (2020). Asuhan Keperawatan Komunitas Peer Bullying Education dalam Upaya Pencegahan dan Pengurangan Perilaku Bullying pada Siswa Kelas VII di SMP Siti Khadijah Padang. Doctoral Dissertation, Universitas Andalas. http://scholar.unand.ac.id/54424/

Salimi, N., Karimi-Shahanjarini, A., Rezapur-Shahkolai, F., Hamzeh, B., Roshanaei, G., \& Babamiri, M. (2019). The Effect of an Anti-Bullying Intervention on Male Students' Bullying-Victimization Behaviors and Social Competence: A Randomized Controlled Trial in Deprived Urban Areas. Journal of Research in Health Sciences, 19(4), e00461. https://pubmed.ncbi.nlm.nih.gov/32291360/

Salmon, S., Turner, S., Taillieu, T., Fortier, J., \& Afifi, T. O. (2018). Bullying Victimization Experiences among Middle and High School Adolescents: Traditional bullying, Discriminatory Harassment, and Cybervictimization. Journal of Adolescence, 63, 29-40. https://doi.org/10.1016/j.adolescence.2017.12.005

Sufriani, S., \& Sari, E. P. (2017). Faktor yang Mempengaruhi Bullying pada Anak Usia Sekolah di Sekolah Dasar Kecamatan Syiah Kuala Banda Aceh. Idea Nursing Journal, 8(3), 1-10. https://doi.org/10.52199/inj.v8i3.9678 
Wahyudi, A., Supriyanto, A., \& Prasetiawan, H. (2018). Peer Guidance untuk Mereduksi Perilaku Bullying Pada Remaja Muhammadiyah. Bagimu Negeri: Jurnal Pengabdian Kepada Masyarakat, 2(1), 50-58. https://ejournal.umpri.ac.id/index.php/bagimunegeri/article/view/618/0 